\title{
Applied SMS-2D in Erosion Simulation of High Entrained Sand Flow Field during Severe Typhoon
}

\author{
K.H. Cheng \& C. Chao \& C.H. Lin \& Y.T. Wang \& H.C. Lin \\ The Sustainable Engineering Research Center, Kao Yuan University, Taiwan
}

\begin{abstract}
Taiwan shaped to the narrow island, whose topography and climatic factors affecting the subject, river current is swift and steep riverbed erosion phenomenon is quite serious, this study Kaohsiung Baolai No.2 Bridge in southern Taiwan as an example and SMS-2D numerical model to simulate flow field during severe typhoon, and thereby calculate the scour depth around pipes by high sand silting, the riverbed elevation change after typhoon can be accurately simulated and provides references of related projects.
\end{abstract}

Keywords- erosion; sand silting; SMS-2D.

\section{INTRODUCTION}

In recent years, due to climate changes caused by changing rainfall patterns, rainfall intensity and latency were significantly increased, leading to hillside erosion accelerated, high concentrations of water entrained landslide and impact piers, not only endanger security after the withdrawal of water accumulation caused the riverbed to rise a lot more, but finally even submerged bridges, thus, bridge maintenance and dredging cause difficulties on. Therefore, the erosion of bed particle by water driven to downstream and the formation of a shallow scour hole in upstream, said bridge safety hazards [1]. Baolai No.2 Bridge is located in Liouguei District, Kaohsiung City, Taiwan, with length-220m, width-9m, a total of five cylindrical diameter- $2.5 \mathrm{~m}$ piers across LaoNong River, whose foundation in diameter-6m. In this study, data were measured within the river bed elevation interpolation space, shown in Fig .1, showing Typhoon Morakot transit entrainment lot of sand, causing severe siltation of river. In order to simulate flood deposition and erosion in riverbed during sever typhoon, Pier sizes and particle size distribution in field is applied for SMS-2D(Surface Water Modeling System) gridding and further subsequent hydrological analyses as case study. This study select near rainfall station to statistic water level and flow data, choice of Typhoon Morakot in 2009/08/05 and Typhoon Fanapi in 2010/09/20 are selected as severe events. In this study, SMS-2D with the appropriate parameters and boundary conditions are set, then with formula estimating scour depth and the main deep channel flows, to evaluate the amount of landslide and sand deposition in the typhoon.

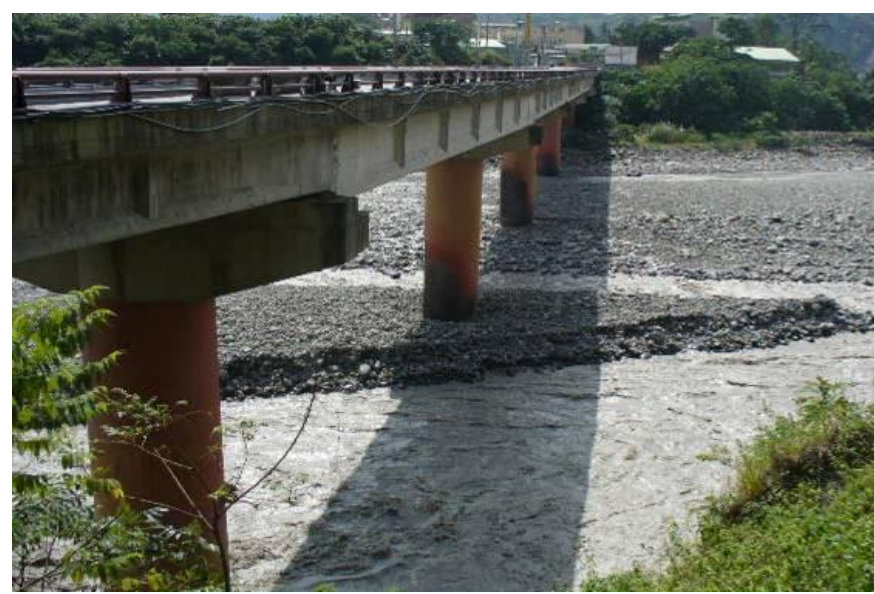

(A)Before Typhoon Morakot

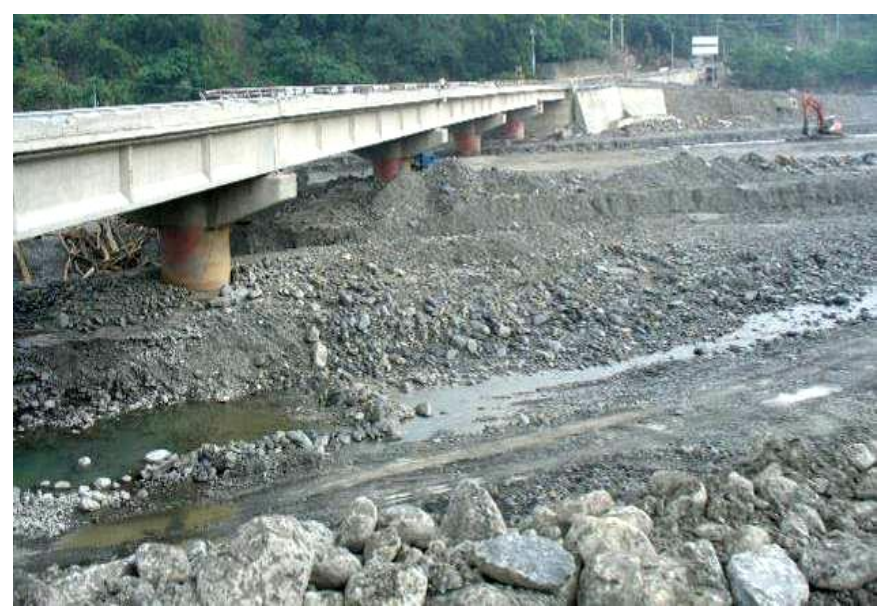

(B)After Typhoon Morakot

Figure 1. Baolai No.2 Bridge during Typhoon Morakot

\section{LITERATURE REFERENCES}

General factors caused by the bow wave of bridge foundation include as: (1) Water flow through the bridge opening between piers increases water blocking area, resulting water level uplift in the bridge site upstream section by constriction scour effect. (2) The height of piers impedes water movement caused by disturbance waves into the impact of pier. The impact of the water wave is the flow kinetic energy into potential energy, resulting in the uplift of the water level. (3) Strong wind or typhoons 
hit the pier by the invasion of height are also high water level obstructs. Scour hole on both sides between piers began to develop, followed quickly by around the pier extending upstream, and then converge in front of piers, whose erosion of the bed material by water driven moved downstream, upstream pier is formed around a shallow scour hole [2-4]. Local scour on the gentle slope, fine quality of the riverbed to its maximum equilibrium scour depth occurred in front of pier and the main erosion mechanism is for the downward flow and the horseshoe vortex. Above detailed are as shown in Fig .2 and Table 1.

TABLE I. THE BRIDGE SCOUR IMPACT TO THE PIER CORRESPONDING LOCATION

\begin{tabular}{|c|c|c|c|}
\hline $\begin{array}{c}\text { Occurred } \\
\text { position }\end{array}$ & $\begin{array}{c}\text { Pier } \\
\text { upstream }\end{array}$ & Around pier & $\begin{array}{c}\text { Pier } \\
\text { downstream }\end{array}$ \\
\hline $\begin{array}{c}\text { Project } \\
\text { phenomeno }\end{array}$ & Bow wave & $\begin{array}{c}\text { river width } \\
\text { narrowing }\end{array}$ & $\begin{array}{c}\text { river width } \\
\text { enlarger }\end{array}$ \\
\hline Scouring & $\begin{array}{c}\text { Local } \\
\text { scouring } \\
\text { flow velocity } \\
\text { and bed shear } \\
\text { increasing } \\
\text { velocity and } \\
\text { bed shear } \\
\text { decreasing }\end{array}$ \\
\hline & sconstriction & $\begin{array}{c}\text { Downstrea } \\
\text { scouring } \\
\text { deposition }\end{array}$ \\
\hline
\end{tabular}

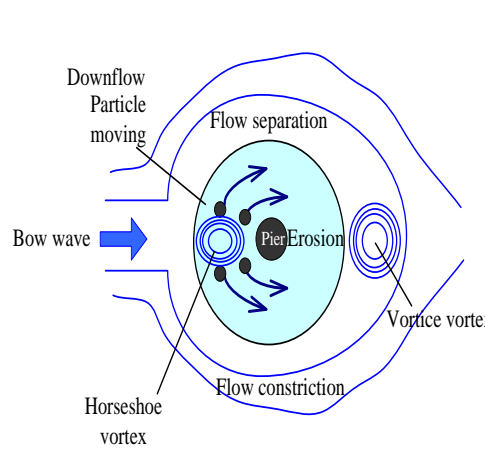

(a) Top-view

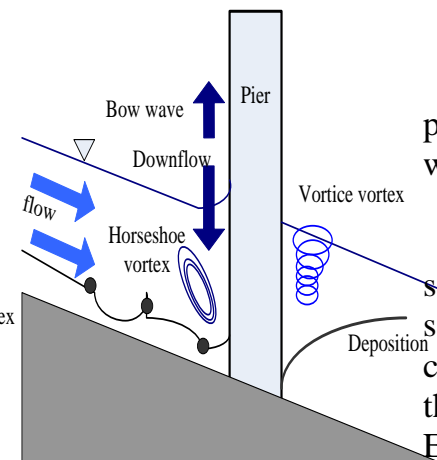

(b) Profile-view

Figure 2. Bridge erosion mechanistic phenomenon around pier

\section{RESULTS AND DISCUSSION}

This study applied SMS-2D (Surface Water Modeling System) modeling based on input of bed material size distribution and topographic level on riverbed to get full section of the river's flow field, in two stages:

1. The river flow speed getting higher by the water level rising, the shear stress increasing on the riverbed to exceed the critical shear stress, thus, the bed particles put away causing erosion phenomenon, and maximum erosion depth consist of general, local and constriction scouring could be calculated by a series of formulas Eq.(1)-(4), separately. [5-8]

When

then
$0<\frac{a}{H_{1}}<25$

$$
\frac{D_{s}}{H_{1}}=1.1\left(\frac{a}{H_{1}}\right)^{0.40} F_{1}^{0.33}
$$

When

$0<\frac{a}{H_{1}}<25$

, then $\left.\frac{\mathrm{D}_{\mathrm{s}}}{\mathrm{H}_{1}}=4 \mathrm{~F}_{1}^{0.33}\right)$

Where $D_{s}$ presents general scour depth in riverbed(m), $H_{1}$ presents water depth in upstream revetment (m), $F_{1}$ presents Froude number in upstream, and $a$ presents revetment length(m).

$h_{s}=h_{1}\left[\left(\frac{B_{1}}{B_{2}}\right)^{9 / 14}-1\right]$

Where $h_{s}$ presents constriction scour depth in $\operatorname{riverbed(m),} h_{1}$ presents water depth in upstream(m), $B_{1}$ presents critical width in upstream $(\mathrm{m})$, and $B_{2}$ presents shrink width in river(m).

$$
\begin{aligned}
& \frac{D_{p}}{h_{2}}=5.5 \times \frac{h_{s}}{h_{2}} \times\left[\left[\frac{\mathrm{h}_{\mathrm{s}}}{11.5 \times h_{2}}+1\right]^{1.7}-1\right] \\
& \text { Where } h_{s} \text { presents local scour } \operatorname{depth}(\mathrm{m}), h_{2}
\end{aligned}
$$

presents water depth before pipe $(\mathrm{m})$, and $D_{p}$ presents water width before $\operatorname{pier}(\mathrm{m})$.

2. The river flow rate getting slows down, the shear stress decreasing on the bed of the river fall, thus, sedimentation rate (falling velocity) greater than the carrying capacity of the water, and the water contained in the sand settlement will cause siltation, formula as below Eq.(5)-(7), separately.

When $0.1 \mathrm{~mm} \leq D_{m} \leq 1 \mathrm{~mm}$, then falling velocity
$\mathrm{w}_{\mathrm{f}}=10 \frac{\mathrm{v}_{1}}{\mathrm{D}_{\mathrm{m}}}\left\{\left[1+\frac{0.01\left(\mathrm{~S}_{\mathrm{g}}-1\right) \mathrm{gD}_{\mathrm{m}}^{3}}{\mathrm{v}_{1}^{2}}\right]^{0.5}-1\right\}$

When $1 m m \leq D_{m} \leq 4 m m$, then falling velocity

$\mathrm{w}_{\mathrm{f}}=1.1\left[\left(\mathrm{~S}_{\mathrm{g}}-1\right) \mathrm{gD}_{\mathrm{m}}\right]^{0.5}$

Where $D_{m}$ presents particle size $(\mathrm{m})$, $S_{g}$ presents density of water flow, ${ }^{v_{l}}$ presents viscosity coefficient of laminar flow.

Bed load siltation

$$
q_{b}\left(D_{m}\right)=1.05 \sqrt{\left(S_{g}-1\right) g D_{m}^{3}} \frac{3.1}{\sqrt{\left(S_{g}-1\right)}}\left(\theta_{m}\right)^{0.5}\left(\theta_{m}-\theta_{c m}\right) F_{r}^{1.1}
$$


Where $\theta_{\mathrm{m}}=\frac{\tau_{\mathrm{b}}}{\rho\left(\mathrm{S}_{\mathrm{g}}-1\right) \mathrm{gD} \mathrm{m}_{\mathrm{m}}}$ presents dimensionless shear stress , $\theta_{c m}=\frac{\tau_{c m}}{\rho\left(S_{g}-1\right) g D_{m}}$ critical shear stress,

$q_{b}\left(D_{m}\right)$ presents bed load of representative particle size in m-item, $\rho$ presents Sand flow fluid density, and $F_{r \text { presents Froude number. }}$

In this study, SMS-2D simulation for Typhoon Morakot in 2009/08/05 and Typhoon Fanapi in 2010/09/20 events in river bed erosion by entering the particle size distribution of rainfall, as shown in Fig .3 and then the maximum scour depth of each pier scour can be calculated in table 2, separately. The sediment transport modeling in this pattern to verify the accuracy of the simulation in Fig .4 and Fig .5.

TABLE II. THE CALCULATED MAXIMUM SCOUR DEPTH(M) TO THE PIER CORRESPONDING LOCATION

\begin{tabular}{|c|c|c|c|c|}
\hline $\begin{array}{c}\text { Typhoon event/pipe } \\
\text { No. }\end{array}$ & P1 & P2 & P3 & P4 \\
\hline Typhoon Morakot & 6.09 & 6.30 & 6.17 & 5.98 \\
\hline Typhoon Fanapi & 5.32 & 5.46 & 5.35 & 5.07 \\
\hline
\end{tabular}

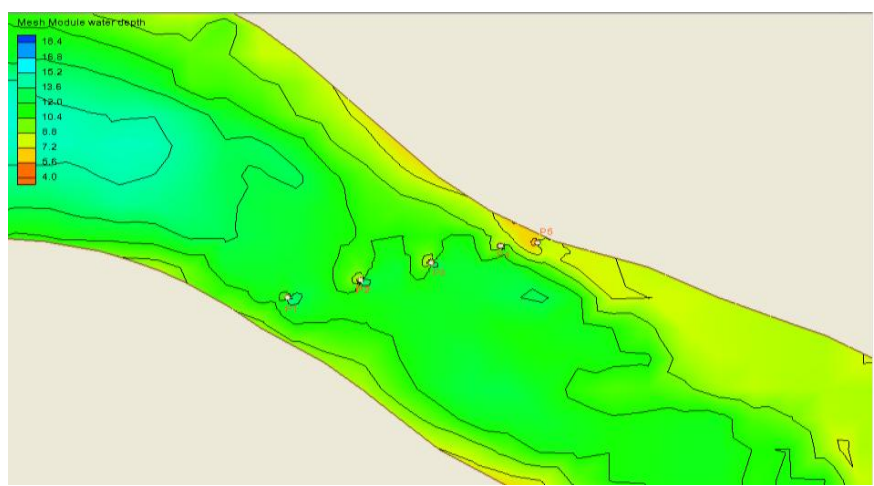

(A)water depth (m)

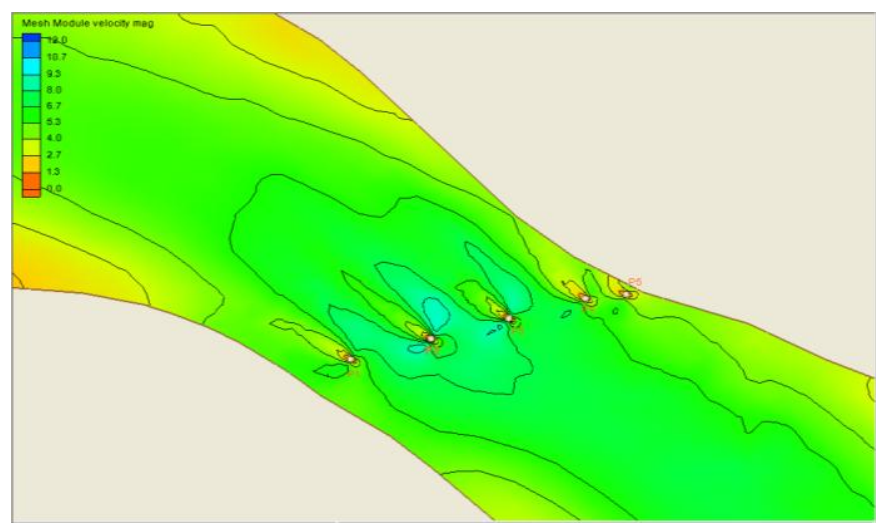

(B)flow velocity $(\mathrm{m} / \mathrm{s})$

Figure 3. Flow field in Baolai No.2 Bridge for simulation of Typhoon Fanapi

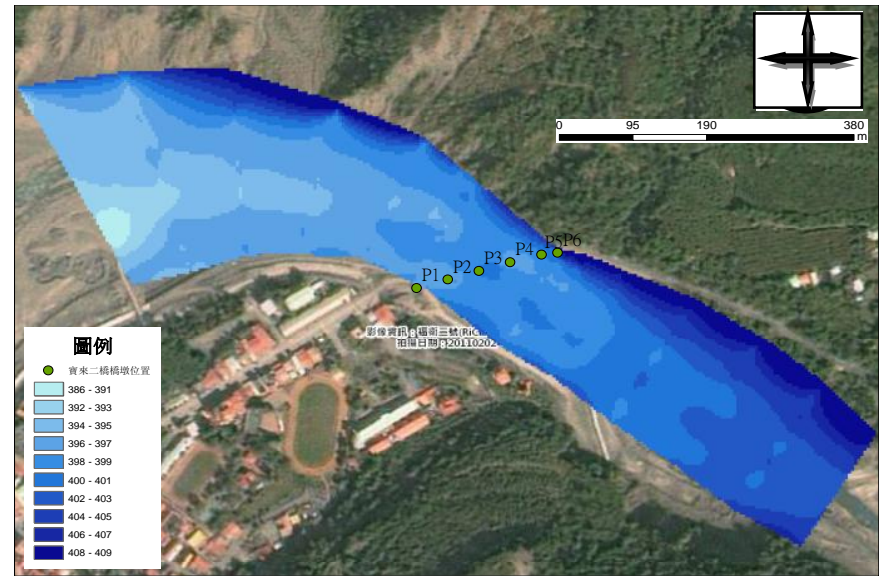

(A)River bed elevation after Typhoon Morakot

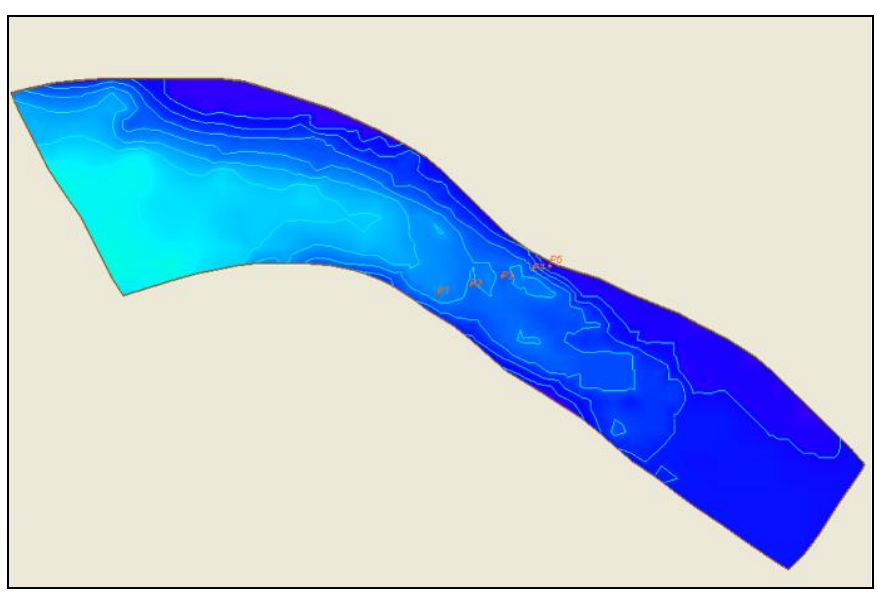

(B)Erosion simulation of Typhoon Morakot

Figure 4. Topographic comparison of Typhoon Morakot

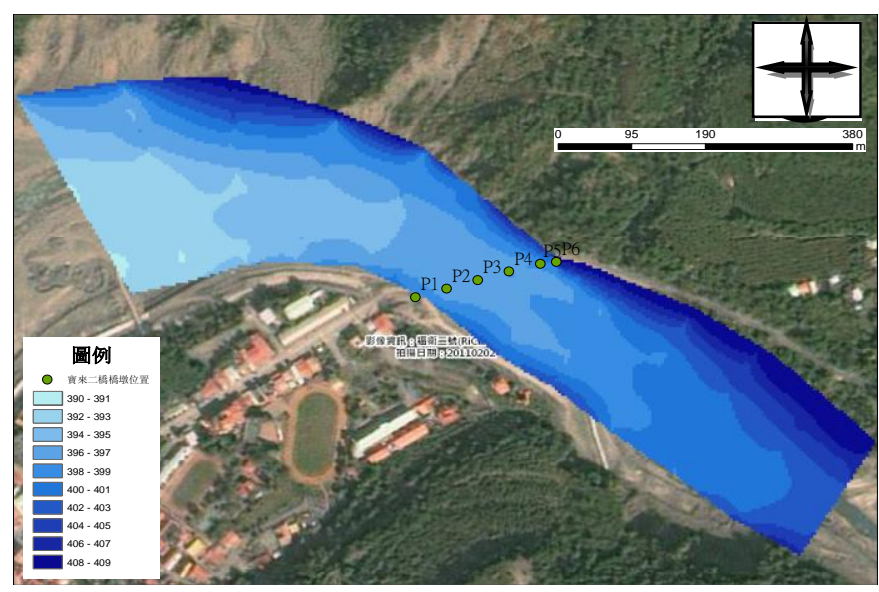

(A) River bed elevation after Typhoon Fanapi 


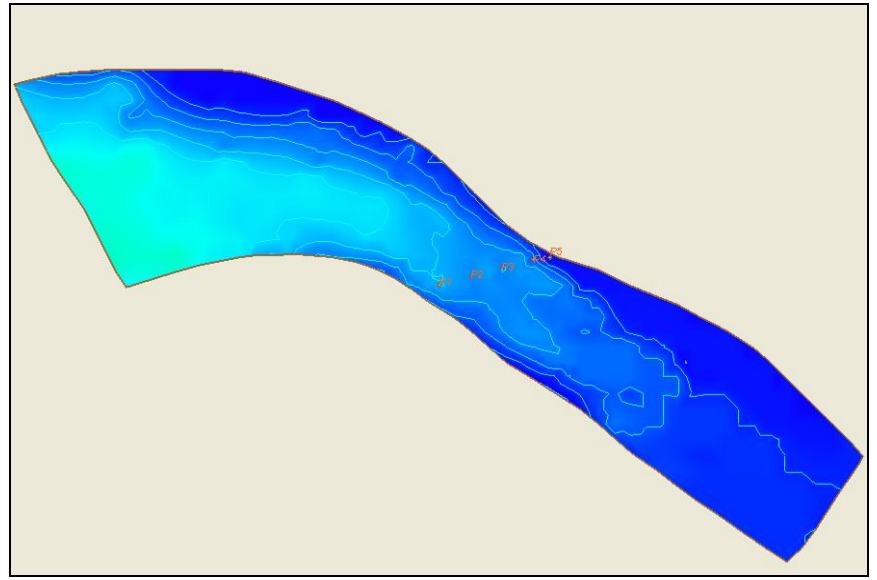

(B) Erosion simulation of Typhoon Fanapi

Figure 5. Topographic comparison of Typhoon Fanapi

\section{CONCLUSIONS}

This study applied SMS-2D module to estimate deposition depth in each finite-element-mesh grid computing in full section of river to simulate river field change with the appropriate sediment transport formula to perform topographic simulation of the river bed scouring, such as constriction velocity on the main deep trough of river bed and its scour protection effect. It is found that increasing rainfall intensity and enlarge duration causes serious erosion and river siltation entrainment a lot, especially pier scour depth of 6 meters in Typhoon Morakot for examples, and the riverbed silt after the recession of 2 to 3 meters, thus, it is recommended to be regularly dredging sand siltation in river leading to safety hazard in bridge. Therefore, there is a certain degree of accuracy, as the relevant units of the design reference.

\section{REFERENCES}

[1] Breusers, H.N.C. \& Raudkivi, A.J. Scouring, edited by IAHR, Hydraulic Structure Design Manual, Vol.2, Belkema.

[2] Melville, B.W. \& Coleman, S.E. 2000. Bridge Scour, edited by Water Resources Publications, LLC., Highlands Ranch, Colorado, USA.

[3] Rijn, L.V. \& Rossum, H.V. \& Termes, P. 1990. Field Verification of 2-D and 3-D Suspended-Sediment Models, Journal of Hydraulic Engineering 116:1270-1288.

[4] Liou, H. \& Dao, D.G. 1991. Bridge Hydraulics, edited by People's Communications Press, pp.167-184.(in Chinese)

[5] Rickenmann, D. 1991. Hyper concentrated Flow and Sediment Transport at Steep Slopes, Journal of Hydraulic Engineering.-ASCE.

[6] Rickenmann, D. \& Rutschmann, D. P. \& McArdell, B.W. 2006. Comparison of flow resistance relations for debris flows using a one-dimensional finite element simulation model, Nat. Hazard Earth Sys. 6:155-165.

[7] O'Brien, J.S. \& Julien, P.Y. \& Fullerton, W.T. 1993. 2-Dimensional Water Flood and Mudflow Simulation, Journal of Hydraulic Engineering Eng.-ASCE 119:244-261.

[8] Ettma, R. \& Mostafa, E.A. \& Melville, B.W. \& Yassin, A.A. 1998. Local Scour at Skewed Piers, Journal of Hydraulic Engineering, ASCE, Vol. 124(7), pp.756-760. 